\title{
Community-Based Home Energy Tune-Up/Audit Programs: A Step-by-Step Guide to Creating and Implementing Energy Equity Programs in Your Community ${ }^{1}$
}

\author{
Alane Humrich, Lee Hayes Byron, Jennison Kipp, Marianne Schmink, Kimberly Davis, and Paul \\ Monaghan $^{2}$
}

\section{Introduction}

This EDIS document is part of a series showing how Extension agents, community activists and sustainability educators can implement a program that reduces energy use and saves money on utility expenses for low-income households. The first in the series (Developing Extension Programming to Help Low-Income Families Save Money and Energy: The Community Weatherization Coalition Model; AEC705) provided an overview of one successful model of a home energy tune-up/audit program in Alachua County, called the Community Weatherization Coalition. This document outlines the basic steps a team would need to complete in order to have an effective energy tune-up/ audit program that is based on community needs and input. It uses programs in Alachua and Sarasota Counties to provide examples of two different approaches to achieving the same goals.

\section{What is a community-based home energy tune-up/audit program?}

High utility bills can be a significant barrier to housing affordability, particularly for low-income residents. While there are many ways for Extension to support efficiency, ranging from educational workshops and device distribution to online educational materials, a comprehensive program will achieve the highest impacts per household. Home Energy Tune-up/Audit programs use trained "energy coach" volunteers to educate on energy conservation and conduct in-home "energy tune-ups" in which household energy and water use are evaluated, efficiency devices are installed, and recommendations for additional savings are provided to the resident. These programs can be easily adapted to Extension programming aimed at community development, household financial savings, and energy and sustainability efforts.

1. This publication is AEC747, one of a series of the Department of Agricultural Education and Communication, UF/IFAS Extension. Original publication date February 2022. Visit the EDIS website at https://edis.ifas.ufl.edu for the currently supported version of this publication.

2. Alane Humrich, program director, Community Weatherization Coalition; Lee Hayes Byron, county Extension director and program Extension agent II, UF/IFAS Extension Sarasota County; Jennison Kipp, Sustainable Floridians state coordinator, Program for Resource Efficient Communities; Marianne Schmink, professor emerita, Latin American studies; Kimberly Davis, Extension agent, Florida A\&M University Cooperative Extension; and Paul Monaghan, associate professor, Extension education, Department of Agricultural Education and Communication; UF/IFAS Extension, Gainesville, FL 32611.

The Institute of Food and Agricultural Sciences (IFAS) is an Equal Opportunity Institution authorized to provide research, educational information and other services only to individuals and institutions that function with non-discrimination with respect to race, creed, color, religion, age, disability, sex, sexual orientation, marital status, national origin, political opinions or affiliations. For more information on obtaining other UF/IFAS Extension publications, contact your county's UF/IFAS Extension office. U.S. Department of Agriculture, UF/IFAS Extension Service, University of Florida, IFAS, Florida A \& M University Cooperative Extension Program, and Boards of County Commissioners Cooperating. Andra Johnson, dean for UF/IFAS Extension. 


\section{What are the steps to develop a community-based home energy tune-up/audit program?}

These programs are comprehensive and require staff capacity, financial resources, and community partnerships. If the full program is not possible for your community at this time, additional options are provided in a separate EDIS document outlining efficiency program models with less resource requirements.

When evaluating whether a Community-Based Home Energy Tune-up/Audit Program may be possible to develop in your community, consider the following steps and program options:

\section{Research}

1. Establish whether your utility has a local education outreach initiative for home energy conservation or whether your community has resources and funding for addressing environmental or social justice issues. These foundational programs could lend themselves easily to home energy audit initiatives. Funding for these programs is essential because there are costs for materials, training, implementation, and evaluation. Current programs in Florida utilize grants and support from utilities and local government sustainability initiatives.

2. Engage and survey local low-income residents and partners to gauge interest and set goals for your home energy tune-up/audit program. These could be neighborhood associations, nonprofits, churches, government agencies or Extension offices. Understanding specific needs and setting local goals is important for determining your target audience, the number of households you intend to reach, and the outcomes you seek, such as overall energy savings or helping those with the greatest need.

\section{Design and Deliver Training}

1. Decide on the curriculum. The Community Weatherization Coalition in Alachua County has developed a comprehensive and tested curriculum that can be shared for use by nonprofits, and it has been modified by UF/ IFAS Extension Sarasota County for their own specific needs. Whatever curriculum you choose, make sure it is adaptable for your local community and their needs.

2. Recruit trainers. Find qualified trainers and presenters via your local utility, educators in related fields, housing agencies, or professional Energy Auditors to create an appealing, engaging, training event taught by a diversity of individuals.

3. Recruit volunteers to participate in the training, via local nonprofit organizations, churches, nearby universities, high schools, community outreach events, etc. Reach out to those individuals who are passionate about social justice, sustainability, climate change, affordable housing, anddoing meaningful, hands-on service. You may also want to reach out to people with knowledge about building science, such as retired construction trades workers and engineers.

4. Conduct training for the program leaders and volunteers. The Community Weatherization Coalition in Alachua County has established a 12-hour Energy Coach training program that combines classroom lecture with hands-on demonstrations and off-site learning, touring multiple types of residential structures. Sarasota County's training was originally 21 hours, with similar components. The training was condensed to 12 hours to accommodate the schedules of a more diverse audience and to allow for a virtual setting. Volunteers learn to inspect/evaluate homes and identify dozens of ways to increase water and energy efficiency, as well as best practices for working alongside residents in their homes. Trainees learn simple, low- and no-cost measures to save households money and natural resources and motivate behavior change.

5. Purchase materials. Home energy tune-ups require some tools and energy/water-saving items, depending on the extent to which changes are to be made in the clients' households. The materials in a tune-up kit can include LED lightbulbs, faucet aerators, shower heads, pipe insulation, HVAC filters, smart power strips, rope caulk/ foam tape, and safety items such as carbon monoxide (CO) detectors and battery replacements for smoke alarms. Tools and other items such as refrigerator coil brushes, pliers, infrared thermometers, and first aid kits can also be included in the kit. CWC volunteers install items with a potential value of $\$ 90$. These costs are often subsidized by local utility education and outreach programs. Sarasota County volunteers install items with a potential value of $\$ 50$, with the costs paid for by a grant from the US Department of Energy.

6. Develop documents and plans for evaluating. Determine whether you need to collect client data via an application and if so, what demographic or income data is needed, particularly if there are funding restrictions. Also, determine what information to collect during the home tune-up to aid in the design of an inspection form. The 
CWC uses several tools to monitor and evaluate their programming, including intake forms (application and prequestionnaire), electronic tune-up records for each household, and a follow-up report and survey sent to all clients. CWC tracks items and appliances inspected, what measures were performed, and the items installed. Sarasota County tracks what is installed in each home, but not information on each participant, relying instead on a partnership with the housing provider.

7. Develop process to identify clients. CWC's model enables residents to request the service directly. Sarasota County's model works with affordable housing providers like the local housing authority to gain access to multiple units in a complex at one time, without direct resident involvement. Programs can recruit clients via community partners/local nonprofits, your city or county housing authority (public housing), outreach events, etc. An important tool for dissemination of this program is word-of-mouth communication among satisfied clients and their neighbors. Sarasota County also obtains clients through 1:1 consultations organized at local churches, partner outreach events, and a yearly back-to-school event hosted by Hope4Communities.

\section{Implementation}

1. Schedule and coordinate home visits. The home energy tune-up must be scheduled to accommodate the volunteers and the residents or housing provider. A minimum of two trained volunteer Energy Coaches will make the visit, and they must have supplies and logistical support. For CWC, the time in the home can last 2-4 hours, and both the client and the volunteers need to be available. For Sarasota County, the time in the home is approximately 30 minutes, depending on whether the resident is home to discuss energy-saving strategies. Sometimes a utility partner or housing provider may be involved as well, which will require additional coordination but can provide additional resources.

\section{Evaluation}

1. Evaluation tools and procedures. Measuring results can help establish impact for utility savings and natural resource conservation. It is also important for reporting to funders and securing future funding. Determine what quantitative and qualitative procedures you want to or have the capacity to perform, such as finding out what data onusage you can acquire from your utility(-ies) to help you evaluate your impact later, and whether you have the resources to coordinate follow-up surveys with your clients. For the CWC, changes in water and energy use are collected from the local municipal utility by the Program for Resource Efficient Communities (PREC) to evaluate the program. Sarasota County tracks what is installed in each home and estimates savings based on those items. They are working on getting actual energy use data from their utility to ground-truth those estimates.

\section{Summary}

A detailed table comparing the approaches of the two county programs is provided below for more information. Once you have completed these steps, the real start of program implementation begins. It requires dedicated staff and resources to support the volunteers, coordinate trainings, conduct outreach to increase the visibility of the program, and schedule the home energy tune-ups and follow up. Keeping volunteers engaged, maintaining interest among community members, and providing feedback to the network of supporters are some of the tasks of the program leaders.

While these Home Energy Tune-Up programs are complex and involve multiple players and additional resources, they are incredibly effective in helping low-income households save money and increase their financial sustainability, while also having significant environmental and equity benefits. Expanding the model into other counties through the Cooperative Extension network would go a long way toward increasing housing affordability and reducing greenhouse gas emissions across Florida.

\section{Publications in This Series}

Developing Extension Programming to Help Low-Income Families Save Money and Energy: The Community Weatherization Model (https://edis.ifas.ufl.edu/publication/WC368).

Using Community-Based Social Marketing to Improve Energy Equity Programs.

Community Based Home Energy Tune-up/Audit Programs: A Step-by-Step Guide to Creating and Implementing Energy Equity Programs in Your Community.

Options for Incorporating Energy Efficiency into Extension Programs: A Menu of Possibilities for Extension Energy Programming in Your Community. 


\begin{tabular}{|c|c|c|}
\hline & CWC, Gainesville (Alachua County) & Sarasota County \\
\hline $\begin{array}{l}\text { (1) Reach out to } \\
\text { local utility }\end{array}$ & $\begin{array}{l}\text { - Gainesville Regional Utilities (GRU) is a publicly } \\
\text { owned utility with a Conservation Services } \\
\text { Department, offering energy surveys and upgrades } \\
\text { (HVAC, water heater, etc.) for qualified low-income } \\
\text { City of Gainesville homeowners through their LEEP } \\
\text { (low-income energy efficiency plus) program. } \\
\text { - Approximately } 1 / 3 \text { of CWC's funding comes from the } \\
\text { City of Gainesville via GRU. }\end{array}$ & $\begin{array}{l}\text { - Florida Power and Light (FPL) is an Investor-Owned } \\
\text { Utility (IOU) that offers limited residential efficiency } \\
\text { education through their website. They have been } \\
\text { involved in some county energy events in the past. } \\
\text { - Water is provided primarily through local } \\
\text { government-managed utilities, although some } \\
\text { private utilities remain active in the county. }\end{array}$ \\
\hline $\begin{array}{l}\text { (2) Survey local } \\
\text { Partners }\end{array}$ & $\begin{array}{l}\text { Partners include the University of Florida, Rebuilding } \\
\text { Together NCF, Alachua Habitat, United Church } \\
\text { of Gainesville, Alachua County, Greater Duval } \\
\text { Neighborhood Association, and more. } \\
\text { Gainesville has a higher-than-average utility rate, } \\
\text { poverty rate, and affordable housing shortage; CWC } \\
\text { aims to help alleviate the energy burden of at least } \\
150 \text { low-income households/year. }\end{array}$ & $\begin{array}{l}\text { - Partners include the Sarasota Housing Authority, local } \\
\text { foundations, United Way of the Suncoast, Salvation } \\
\text { Army, Children First, and more. } \\
\text { - Sarasota County has relatively low utility rates, but } \\
\text { inefficient housing for low-income residents as well as } \\
\text { an affordable housing shortage. }\end{array}$ \\
\hline $\begin{array}{l}\text { (3) Decide on } \\
\text { Curriculum }\end{array}$ & $\begin{array}{l}\text { - Comprehensive combination of classroom lecture, } \\
\text { demonstration stations, and off-site learning. } \\
\text { Lecture topics covered include why energy } \\
\text { conservation is important, understanding utility } \\
\text { bills and usage, evaluating HVAC systems and attic } \\
\text { insulation, household water efficiency, and more. } \\
\text { - Attendees are taught not only how to inspect homes, } \\
\text { but the best practices for working alongside residents } \\
\text { in their homes, social sensitivity, and safety. }\end{array}$ & $\begin{array}{l}\text { - Similar training content and structure as CWC. } \\
\text { - Additional topics include introductions to green } \\
\text { building, solar, and indoor environmental health. } \\
\text { - In addition to how to inspect homes, volunteers } \\
\text { are also trained on the social sensitivity and safety } \\
\text { components, as well as how to teach Energy Upgrade } \\
\text { workshops and conduct consultations. }\end{array}$ \\
\hline (4) Recruit Trainers & $\begin{array}{l}\text { - CWC trainers are local community members who } \\
\text { volunteer their time to present. } \\
\text { Trainers are from GRU (local utility), UF (professors/ } \\
\text { educators in related fields such as Engineering), } \\
\text { housing agencies, retired professional Energy } \\
\text { Auditors, and current active Energy Coaches (mentor } \\
\text { volunteers). } \\
\text { A diversity of individuals creates a more engaging } \\
\text { event. }\end{array}$ & $\begin{array}{l}\text { Trainers are from FPL, UF/IFAS Extension Sarasota } \\
\text { County and Sarasota County Public Utilities } \\
\text { departments, Department of Health, University of } \\
\text { Florida, professional auditors, and Sarasota Housing } \\
\text { Authority. }\end{array}$ \\
\hline $\begin{array}{l}\text { (5) Recruit } \\
\text { Volunteers }\end{array}$ & $\begin{array}{l}\text { Most trainees recruited from the University of Florida } \\
\text { (Sustainability \& Built Environment major and others), } \\
\text { United Church of Gainesville (active retirees), through } \\
\text { social media and from local tabling/community } \\
\text { outreach events. }\end{array}$ & $\begin{array}{l}\text { - The first two rounds of trainees included primarily } \\
\text { residents active in local environmental organizations } \\
\text { and other nonprofits. Recruiting for future trainings } \\
\text { will target similar volunteers as CWC's program. }\end{array}$ \\
\hline (6) Conduct Training & $\begin{array}{l}\text { - Three part, 12-hour, volunteer Energy Coach training } \\
\text { program. Days } 1 \text { and 2: classroom/online lecture with } \\
\text { hands-on demonstrations; day three: off-site learning } \\
\text { event touring multiple types of residential structures } \\
\text { that concludes with a cookout and graduation/ } \\
\text { certificate ceremony. } \\
\text { Graduates have been introduced to inspecting homes } \\
\text { and identifying (and installing) dozens of simple low- } \\
\text { and no-cost measures to save households money and } \\
\text { natural resources and motivate behavior change. }\end{array}$ & $\begin{array}{l}\text { Previously held as a five part, } 21 \text {-hour volunteer } \\
\text { Energy Coach training program. Sessions } 1 \\
\text { through } 4 \text { were classroom lecture with hands-on } \\
\text { demonstrations; session five was at a Sarasota } \\
\text { Housing Authority property learning hands on how to } \\
\text { conduct the in-home evaluation. } \\
\text { The training program has been condensed to a } \\
\text { four-part, 12-hour session to better accommodate } \\
\text { the working and school schedules of interested } \\
\text { volunteers, and to allow for a virtual setting. In-person } \\
\text { hands-on training is an additional session. }\end{array}$ \\
\hline
\end{tabular}




\section{CWC, Gainesville (Alachua County)}

(7) Materials $\quad$ - CWC materials are valued at approximately $\$ 90$ / home.

- $\quad$ Kits include items for installation such as LED lightbulbs, low-flow faucet aerators and showerheads, pipe insulation for water heaters, switch/outlet gaskets, toilet leak detecting tabs, and safety items, such as carbon monoxide detectors.

- Tools and other items that stay in the kit include refrigerator coil brushes, pliers, infrared thermometers, and first aid kits.

\section{Sarasota County}

- Sarasota County materials are valued at approximately $\$ 50 /$ home.

- Kits include similar items to CWC, plus HVAC filters, smart power strips, and rope caulking/foam tape.

- Similar tools as CWC are also included in the kit.

- In addition to the kits used in households Sarasota County gives away Energy Upgrade Kits at educational workshops. These kits are valued at approximately $\$ 30 /$ home. These kits include LED lightbulbs, water aerators, showerheads, wall/outlet gaskets, rope caulk/foam tape, a smart power strip, informational booklet, and more.

(8) Evaluation Tools CWC uses several tools to monitor and evaluate programming, including

- Intake forms (application and prequestionnaire)

- $\quad$ Electronic tune-up records (spreadsheet) for each household

- Follow-up report and satisfaction survey sent to all clients.

- Additional measures of changes in water and energy use are also collected from the local utility by UF's Program for Resource Efficient Communities (PREC). The methodology used by PREC is detailed in an EDIS document.

(9) Clients

- Referred from community partners agencies and nonprofits (e.g., Rebuilding Together, Alachua Habitat, Gainesville Housing Authority).

- $\quad$ Recruited by staff and volunteers at outreach events and via online marketing such as social media and website. Tune-ups are focused on client concerns and their participation, education and empowerment.

- A key component of recruitment has become word of mouth from satisfied clients.
- Sarasota County tracks each item installed in each home and estimates savings based on that information.

- Working with FPL to receive anonymous utility data on participating homes.
- Sarasota Housing Authority (SHA) provides access to several of their units in a combined effort called an "Energy Sweep." The residents are notified through door hangers or similar notification at least 2 days in advance. This means they are not always home, but when they are, the Energy Coaches discuss what is being done, answer any questions, and provide additional suggestions if they are interested. Energy Coaches aim to achieve behavior change where possible.

- Additional affordable housing providers will be recruited to facilitate similar Energy Sweeps once all SHA units have been completed.

- Clients are also recruited through 1:1 consultations organized at local churches, partner outreach events, and a yearly back to school event hosted by Hope4Communities.

(10) Coordinate home visits
- CWC home energy tune-ups are scheduled to accommodate residents and volunteer energy coaches during daylight hours every day of the week.

- 2-3 trained volunteer Energy Coaches perform a tune-up, averaging 2-4 hrs.

- $\quad$ CWC staff preps and coordinates the paperwork and supply kit dispersal and offers support (including being on call in case of an emergency).
- $\quad$ Energy Sweeps are scheduled to ensure SHA staff and Energy Coach volunteers are both available. FPL staff have also assisted in some Energy Sweeps.

- At least 2 trained Energy Coaches conduct the evaluation and install the items in each unit, averaging $\sim 30$ minutes each.

- UF/IFAS Extension Sarasota County staff facilitates the logistics, provides the supplies, and attends each Energy Sweep. 